\title{
ANALISIS RISIKO KESEHATAN LINGKUNGAN AKIBAT PAPARAN NITRIT DAN KADMIUM DARI AIR SUMUR DI KELURAHAN TARUS
}

\section{Environmental Health Risk Analysis Due to Exposure Nitrit and Cadmium from Well Water on Tarus Village}

\author{
Charly Mutiara1)*, Wilhelmus I.I. Mella2) dan Suwari2)
}

1) Fakultas Pertanian Universitas Flores Jln. Samratulangi, Kabupaten Ende 86318

2) Universitas Nusa Cendana, Jl. Adisucipto, Kota Kupang, 85148

\begin{abstract}
The well water in Tarus Village is suspected to have been contaminated with nitrite and cadmium from excessive use of SP-36 and Urea fertilizers. Therefore, this study was conducted to compare the concentrations of nitrite and cadmium contaminants in well water in rice fields and settlements with drinking water quality standard thresholds and to predict the magnitude of the risk of contaminants to human health. This experimental descriptive study used water from 10 wells each from the rice fields and settlements. Nitrite and cadmium levels were analyzed spectrophotometrically (SNI 06-6989.9-2004) and atomic absorption spectrophotometry (SSA) - flame (SNI 6989.16: 2009). Water quality standards and drinking water raw water are based on PP 82 of 2001 and PerMenKes 492 of 2010. Prediction of risks to human health is carried out based on the risk analysis method of Public Health Assessment. The results showed that in the rice fields there were three wells whose water contained nitrite and five wells in residential areas, but they were still below the drinking water quality standard. As for cadmium, in rice fields, there are eight wells whose water contains cadmium and in residential areas, there are seven wells, all of which are above drinking water quality standards. Risk analysis shows that nitrite from wells in rice fields and settlements does not pose a health risk. Meanwhile, cadmium from water in rice fields and settlements is at risk of as much as 14 wells.
\end{abstract}

Keywords: Groundwater, nitrite, cadmium, risk.

\section{ABSTRAK}

Air sumur di Kelurahan Tarus diduga telah terkontaminasi nitrit dan kadmium yang berasal dari pemakaian secara berlebihan pupuk SP-36 dan Urea. Oleh karena itu, penelitian ini telah dilaksanakan untuk membandingkan konsentrasi kontaminan nitrit dan kadmium dalam air sumur di daerah persawahan dan pemukiman dengan ambang baku mutu air baku air minum dan memprediksi besarnya risiko dari kontaminan terhadap kesehatan manusia. Penelitian deskriptif eksperimental ini menggunakan air dari masing-masing 10 sumur dari daerah persawahan dan pemukiman. Kadar nitrit dan kadmium dianalisis secaraspektrofotometri (SNI 06-6989.9-2004) dan spektrofotometri serapan atom (SSA) - nyala (SNI 6989.16:2009). Baku mutu air dan air baku air minum berdasarkan PP 82 tahun 2001 dan PerMenKes 492 tahun 2010. Prediksi risiko terhadap kesehatan manusia dilakukan berdasarkan metode analisis risiko Public Health Assessment. Hasil penelitian menunjukkan bahwa di daerah persawahan terdapat tiga sumur yang airnya mengandung nitrit dan lima sumur pada daerah pemukiman, namun masih berada di bawah standar baku mutu air minum. Sedangkan untuk kadmium, di daerah persawahan terdapat delapan sumur yang airnya mengandung cadmium dan di pemukiman terdapat tujuh sumur, dimana semuanya berada di atas standar baku mutu air minum. Analisis risiko menunjukkan bahwa nitrit dari sumur di persawahan dan pemukiman tidak berisiko terhadap kesehatan. Sedangkan kadmium dari air di persawahan dan pemukiman berisiko sebanyak 14 sumur.

Kata kunci: Air tanah, nitrit, kadmium, risiko

\section{PENDAHULUAN}

Perlindungan terhadap air perlu dilakukan, karena adanya permasalahan kuantitas dan kualitas pada air. Pada tahun 2015, diperkirakan kebutuhan air penduduk NTT di musim kemarau akan mengalami minus hingga 37 juta $\mathrm{m}^{3}$ (Suwari, 2011). Jumlah air yang minus tersebut, diperparah lagi dengan tidak terjaminnya kualitas air yang baik bagi kesehatan manusia. Oleh karena itu, para pengguna harus memanfaatkan air secara bijaksana, sehingga dapat tersedia secara berkelanjutan dan berkualitas baik.

Penurunan kualitas air ini disebabkan oleh berbagai buangan limbah dari domestik, industri, pertanian dan kegiatan lainnya sehingga menyebabkan air tercemar (Suwari, 2011; Genafati et al., 2005; Villa, 2010; Raja dan
Venkatesan, 2010; Tiwari, 2011; Akiwumi et al., 2012). Air yang telah tercemar, akan menimbulkan berbagai permasalahan kesehatan bagi manusia, karena itu diperlukan adanya informasi tentang kualitas air dari setiap badan-badan air di setiap daerah, terutama badan air yang dimanfaatkan untuk air minum.

Badan air yang secara umum dimanfaatkan masyarakat untuk keperluan air minum adalah air tanah. Potensi air tanah di suatu daerah bergantung pada kondisi hujan, topografi dan geologi di daerah tersebut. Wilayah Pulau Timor yang mempunyai potensi air terbesar terdapat di Kabupaten Kupang yakni mencapai 71.94 juta $\mathrm{m}^{3}$ dari total 106.25 juta $\mathrm{m}^{3}$ yang tersedia (Suwari, 2011). Jumlah air yang tinggi ini, dapat dijumpai pada Kelurahan Tarus. 
Tarus adalah salah satu daerah di Kabupaten Kupang yang tidak memiliki masalah dengan kuantitas air. Kondisi ini memungkinkan diusahakannya kegiatan pertanian yang rutin sepanjang tahun. Keadaan yang menguntungkan masyarakat di Tarus ini, juga dapat menyebabkan terjadinya penurunan kualitas air. Hal tersebut dapat terjadi karena usaha pertanian yang dilakukan menggunakan pupuk anorganik sehingga dapat meningkatkan zat-zat pencemar pada badan-badan air (Genafati et al., 2005; Dimopoulus, 2003; Villa, 2010; Rawat et al., 2012).

Zat-zat pencemar yang biasanya ada karena kegiatan pertanian adalah nitrit dan kadmium, yang berasal dari pemakaian pupuk urea (nitrit) dan SP-36 (kadmium) dengan dosis melebihi yang dianjurkann (400 kg Urea ha ${ }^{-1}$ dan $200 \mathrm{~kg} \mathrm{SP}-36 \mathrm{ha}^{-1}$ ). Selain dari pupuk kimia, keberadaan nitrit dan kadmium dapat berasal dari limbah domestik dan septiktank (Aswadi, 2006; Villa, 2010; Akiwumi et al., 2012). Studi ADKL (analisis dampak kesehatan lingkungan) yang dilakukan untuk menilai kualitas air sumur gali di Kabupaten Sleman, Daerah Istimewa Yogyakarta, menunjukkan telah terjadipencemaran, sehingga tidak memenuhi standar kualitas air minum yang telah ditetapkan (Genafati et al., 2005). Jika keadaan ini terus berlangsung, maka dapat berdampak pada kesehatan masyarakat.

Dampak bagi kesehatan manusia, jika mengkonsumsi air yang telah tercemar nitrit, adalah terhambatnya peredaran darah, kerusakan pada butiran darah merah serta tekanan darah tinggi (Villa, 2010; Akiwumi et al., 2012), sedangkan kadmium jika dikonsumsi dapat mengakibatkan kerusakan pada ginjal, paru-paru, dan tulang (Corrosion-doctors, 2008; Alloway dan Ayres, 1993; Slamet, 2002; Rawat et al., 2012). Untuk mencegah terjadinya permasalahan kesehatan tersebut, maka ditetapkanlah kadar nitrit dan kadmium di dalam PP No 82 tahun 2001 (tentang pengelolaan kualitas air dan pengendalian pencemaran air) sebagai ambang batas di dalam air baku air minum yakni sebesar $0.06 \mathrm{mg} \mathrm{L}^{-1}$ untuk nitrit (sebagai nitrogen) dan $0.01 \mathrm{mg} \mathrm{L}^{-1}$ untuk kadmium. Sementara sesuai PerMenKes No. 492 tahun 2010 tentang persyaratan kuantitas air minum, mensyaratkan kadar nitrit maksimum pada air minum (sebagai nitrogen) sebesar 0.9 $\mathrm{mg} \mathrm{L}^{-1}$ dan kadmium $0.003 \mathrm{mg} \mathrm{L}^{-1}$.

Air tanah yang dimanfaatkan warga di kelurahan Tarus sebagai sumber air minum belum diketahui kadar nitrit dan kadmium di dalamnya. Karena itu, peneliti merasa perlu mendapatkan informasi tentang kadar nitrit dan kadmium dalam air tanah dan membandingkan kadar keduanya dengan nilai baku mutu, serta melakukan prediksi risiko kesehatan bila kedua zat tersebut terdeteksi di dalam air tanah.

\section{BAHAN DAN METODE}

Penelitian ini merupakan penelitian deskriptif eksperimental dengan menggunakan air dari 20 sumur di daerah persawahan dan pemukiman di Kelurahan Tarus Kabupaten Kupang Provinsi Nusa Tenggara Timur. Pengambilan sampel air tanah berdasarkan SNI 6989.58: 2008 tentang metoda pengambilan contoh air tanah. Alat dan bahan yang digunakan dalam penelitian adalah Global postioning system (GPS), kotak pendingin, spektrofotometer, Spektrofotometer Serapan Atom, serta air sumur.

Kadar nitrit dan cadmium di dalam air dianalisis secara spektrofotometri (SNI 06-6989.9-2004) dan spektrofotometri serapan atom (SSA) - nyala (SNI 6989.16:2009), kemudian dideskripsikan risikonya setelah dibandingkan dengan standar baku mutu air minum dari PP 82 tahun 2001 dan PerMenKes 492 tahun 2010 dan analisis risiko kesehatan. Metode analisis untuk memprediksi besar risiko kontaminasi nitrit dan kadmium pada manusia, menggunakan metode Public Health Assesment (PHA) (ATSDR, 2005). Metode PHA dilaksanakaan sebagai berikut:

Pendugaan asupan (I) (ATSDR, 2005):

$$
\mathrm{I}=\frac{C x R x f_{E} x D_{t}}{W_{b} x t_{a v g}}
$$

Keterangan:

$\mathrm{I}=$ Asupan (intake), $\mathrm{mg} \mathrm{kg}^{-1}$ hari $^{-1}$

$\mathrm{C}=$ Konsentrasi risk agent, $\mathrm{mg} \mathrm{L}^{-1}$

$\mathrm{R}=$ Laju asupan atau konsumsi, $\mathrm{L}_{\text {hari }}{ }^{-1}$

$\mathrm{f}_{\mathrm{E}}=$ Frekuensi kontak, hari tahun ${ }^{-1}$

$\mathrm{D}_{\mathrm{t}}=$ Durasi kontak, tahun (30 tahun untuk nilai default residensial

$\mathrm{W}_{\mathrm{b}}=$ Berat badan, $\mathrm{kg}$

$t_{a v g}=$ Periode waktu rata-rata $\left(D_{t} \times 365\right.$ hari tahun $^{-1}$

Setelah didapat nilai asupan (I), maka dicari nilai tingkat risiko $(\mathrm{RQ})=\mathrm{I} / \mathrm{RfD}$. Bila ternyata $\mathrm{RQ}>1$ berarti ada risiko potensial sedangkan bila $R Q<1$ untuk sementara pencemaran masih aman dan belum perlu dikendalikan.

Keterangan:

$\mathrm{RQ}=$ tingkat risiko

I = prediksi banyaknya unsur yang dikonsumsi oleh konsumen

$\mathrm{RfD}=$ reference dose $($ dosis referensi $)=$ nilai kuantitatif toksisitas risk agent yang telah ditetapkan EPA (Environmental Protection Agency)

Analisis risiko dapat dimodifikasi untuk memprediksi tingkat risiko kesehatan sesuai dengan keadaan penduduk yang real, sebagai berikut:

a. Prediksi risiko untuk durasi pemaparan 5 atau 10 tahun, maka variabel Dt (durasi pemaparan) pada persamaan (1), diganti dengan waktu 5 tahun, 10 tahun dan 20 tahun. Informasi prediksi risiko dalam kurun waktu yang lebih pendek ini diharapkan dapat meningkatkan tingkat kewaspadaan terhadap risiko paparan kontaminan

b. Prediksi durasi pemaparan lamanya risiko mulai harus dikendalikan, yaitu dengan memodifikasi persamaan (1), dan nilai I (pendugaan asupan), disubsitusi dengan nilai RfD yang sesuai. Hasil modifikasi sebagai berikut:

$$
\mathrm{Dt}=\frac{R f D x W b x t_{\text {avg }}}{C x R x f_{E}} \text { (tahun) }
$$

Manajemen risiko untuk mengetahui laju konsumsi air minum (sesuai kadar kontaminan yang telah diketahui) berdasarkan berat badan penduduk yang sebenarnya. Untuk mengetahui hal ini, maka dapat 
dilakukan modifikasi terhadap persamaan pendugaan asupan (I) dengan mensubsitusi nilai I dengan nilai RfD yang sesuai, maka diperoleh persamaan sebagai berikut:

$$
\mathrm{R}=\frac{R f D x W_{b} x t_{\text {avg }}}{C x f_{E} x D_{t}}\left(\text { L hari }^{-1}\right)
$$

\section{HASIL DAN PEMBAHASAN}

\section{Nitrit di Persawahan}

Hasil analisis air yang diambil dari 10 sumur di daerah persawahan menunjukan bahwa tiga sampel air tanah terbaca kadar nitrit di dalamnya, sedangkan tujuh sampel kadar nitritnya lebih kecil dari batas deteksi alat. Hal ini dapat dilihat pada Tabel 1 di bawah ini.

Tabel 1. Hasil analisis kadar nitrit di persawahan

\begin{tabular}{cccc}
\hline \multirow{2}{*}{ Sampel } & $\begin{array}{c}\text { Kadar nitrit } \\
(\text { N-Nitrit })\end{array}$ & $\begin{array}{c}\text { Baku mutu PP 82 } \\
\left(\text { N-Nitrit }=6 \times 10^{-2}\right)\end{array}$ & $\begin{array}{c}\text { Baku mutu PerMenKes } 492 \\
\left(\text { N-Nitrit }=9 \times 10^{-1}\right)\end{array}$ \\
\cline { 2 - 4 } & & \multicolumn{1}{c}{$\left.\mathrm{mg} \mathrm{L}^{-1}\right)$} & \\
\hline 1 & $0.24 \times 10^{-2}$ & $<\mathrm{BM}$ & $<\mathrm{BM}$ \\
2 & $<1 \times 10^{-3}$ & $<\mathrm{BM}$ & $<\mathrm{BM}$ \\
3 & $<1 \times 10^{-3}$ & $<\mathrm{BM}$ & $<\mathrm{BM}$ \\
4 & $<1 \times 10^{-3}$ & $<\mathrm{BM}$ & $<\mathrm{BM}$ \\
5 & $<1 \times 10^{-3}$ & $<\mathrm{BM}$ & $<\mathrm{BM}$ \\
6 & $<1 \times 10^{-3}$ & $<\mathrm{BM}$ & $<\mathrm{BM}$ \\
7 & $<1 \times 10^{-3}$ & $<\mathrm{BM}$ & $<\mathrm{BM}$ \\
8 & $0.24 \times 10^{-4}$ & $<\mathrm{BM}$ & $<\mathrm{BM}$ \\
9 & $1.24 \times 10^{-2}$ & $<\mathrm{BM}$ & $<\mathrm{BM}$ \\
10 & $<1 \times 10^{-3}$ & $<\mathrm{BM}$ & \\
\hline
\end{tabular}

Keterangan: Kadar nitrit hasil pengukuran spektrofotometer dengan $\mathrm{R}^{2}$ absorbsi = 0,998; < $\mathrm{BM}=$ lebih kecil dari baku mutu.

Keberadaan nitrit dalam air tanah dapat bersumber dari proses alamiah dan aktivitas antropogenik. Secara alamiah keberadaan nitrit di alam berasal dari siklus nitrogen. Nitrogen atmosfer diikat oleh tanaman legum dan diubah menjadi bentuk yang tersedia bagi tanaman (Bryan dan Lozcalso, 2011). Nitrogen yang ada pada tanaman dapat kembali ke dalam tanah, jikatanaman mati dan terdekomposisi. Nitrogen adalah unsur yang mudah tercuci, sehingga dapat terbawa dari tanah ke dalam perairan. Siklus nitrogen ini menyebabkan adanya nitrit di dalam perairan. Secara alami konsentrasi nitrit di perairan sekitar 1 x $10^{-3} \mathrm{mg} \mathrm{L}^{-1}$ (Effendi, 2003). Sumber antropogenik yang menyebabkan adanya nitrit di perairan adalah buangan limbah dari aktivitas rumah tangga, septik tank dan pemakaian pupuk anorganik yang mengandung nitrogen.

Pupuk nitrogen yang dipakai oleh petani di kelurahan Tarus adalah pupuk urea. Pupuk urea mengandung $45 \%$ nitrogen, dan dipakai dengan dosis yang tinggi oleh para petani. Dosis pupuk yang diberikan setiap musim tanam adalah $400 \mathrm{~kg} \mathrm{ha}^{-1}$. Selain pemakaian pupuk, keberadaan penduduk di daerah persawahan juga mempengaruhi keberadaan nitrit di dalam air. Daerah persawahan ini terdiri atas 309 kepala keluarga dengan 1,253 jiwa. Keberadaan penduduk ini tidak terlepas dari adanya buangan limbah rumah tangga dan penggunaan septik tank, sehingga mempengaruhi adanya nitrit di dalam air.
Nitrit di dalam air berada dalam kesetimbangan dengan nitrat dan amonium. Nitrit merupakan senyawa intermedia dari kedua senyawa tersebut. Keberadaan ketiga unsur ini dipengaruhi oleh adanya oksigen. Saat oksigen pada air tanah tinggi (oksidasi), maka ammonium akan diubah menjadi nitrit, lalu menjadi nitrat, sedangkan saat oksigen di dalam air rendah, nitrat diubah menjadi nitrit, kemudian menjadi amonium (Bryan dan Lozcalso, 2011; Rawat et al., 2012; Villa, 2012).

Pemerintah telah menetapkan ambang batas untuk mengatur kadar nitrit di dalam air. Ambang batas kadar nitrit perairan tertera di dalam PP 82 tahun 2001 tentang pengelolaan kualitas air dan pengendalian pencemaran air dan PerMenKes 492 tahun 2010 tentang persyaratan kualitas air minum. Ambang batas kadar nitrit yang ditetapkan untuk air baku air minum menurut PP 82 adalah $0,06 \mathrm{mg} \mathrm{L}^{-1}$ dan ambang batas di dalam PerMenKes adalah $0,9 \mathrm{mg} \mathrm{L}^{-1}$.

Nitrit dalam air tanah yang dijadikan sampel penelitian ini masih berada di bawah ambang batas yang ditetapkan di dalam PP 82 dan PerMenKes 492. Namun keberadaan nitrit ini perlu diwaspadai, karena di dalam tubuh (lambung), nitrat dapat diubah menjadi nitrit oleh sejenis bakteri sehingga dapat meningkatkan kadar nitrit di dalamtubuh (Utama, 2007; Viila, 2010; Rawat et al., 2012).

\section{Nitrit di Pemukiman}

Hasil pengukuran nitrit menggunakan spektrofotometer dengan kemampuan deteksi $0.001 \mathrm{mg} \mathrm{L}$ ${ }^{1}$ menunjukkan bahwa dari sepuluh sampel air, lima sampel terdeteksi dengan kadar $0.75 \times 10^{-3} \mathrm{mg} \mathrm{L}^{-1}, 1.26 \times 10^{-2} \mathrm{mg}$ $\mathrm{L}^{-1}, 1.72 \times 10^{-3} \mathrm{mg} \mathrm{L}^{-1}, 1.96 \times 10^{-3} \mathrm{mg} \mathrm{L}^{-1}$ dan $1.48 \times 10^{-3}$ $\mathrm{mg} \mathrm{L}^{-1}$. Hal ini dapat terlihat pada Tabel 2 di bawah ini.

Tabel 2. Konsentrasi nitrit di daerah pemukiman dan baku mutu

\begin{tabular}{cccc}
\hline Sampel & $\begin{array}{c}\text { Kadar nitrit } \\
(\text { N-Nitrit })\end{array}$ & $\begin{array}{c}\text { Baku mutu } \\
\text { PP 82 } \\
\left(\text { N-Nitrit }=6 \times 10^{-2}\right)\end{array}$ & $\begin{array}{c}\text { Baku mutu } \\
\text { PerMenKes 492 } \\
\left(\text { N-Nitrit }=9 \times 10^{-1}\right)\end{array}$ \\
\cline { 2 - 4 }$\left(\mathrm{mg} \mathrm{L}^{-1}\right)$ & \\
\hline 1 & $<1 \times 10^{-3}$ & $<\mathrm{BM}$ & $<\mathrm{BM}$ \\
2 & $<1 \times 10^{-3}$ & $<\mathrm{BM}$ & $<\mathrm{BM}$ \\
3 & $0.75 \times 10^{-3}$ & $<\mathrm{BM}$ & $<\mathrm{BM}$ \\
4 & $<1 \times 10^{-3}$ & $<\mathrm{BM}$ & $<\mathrm{BM}$ \\
5 & $<1 \times 10^{-3}$ & $<\mathrm{BM}$ & $<\mathrm{BM}$ \\
6 & $1.26 \times 10^{-2}$ & $<\mathrm{BM}$ & $<\mathrm{BM}$ \\
7 & $1.72 \times 10^{-3}$ & $<\mathrm{BM}$ & $<\mathrm{BM}$ \\
8 & $1.96 \times 10^{-3}$ & $<\mathrm{BM}$ & $<\mathrm{BM}$ \\
9 & $<1 \times 10^{-3}$ & $<\mathrm{BM}$ & $<\mathrm{BM}$ \\
10 & $1.48 \times 10^{-3}$ & $<\mathrm{BM}$ & \\
\hline
\end{tabular}

Keterangan: Kadar nitrit hasil pengukuran spektrofotometer dengan $\mathrm{R}^{2}$ absorbsi = 0.998; $<\mathrm{BM}=$ lebih kecil dari baku mutu.

Unsur nitrit yang terdapat di dalam air tanah ini menggambarkan bahwa berbagai aktivitas di daerah pemukiman dapat meningkatkan kandungan nitrit pada badan air (Villa, 2010).

Keberadaan nitrit dalam air tanah di daerah pemukiman dapat bersumber dari aktivitas penduduk. Penduduk sebanyak 2,747 jiwa di wilayah ini dengan aktivitas kesehariannya menghasilkan limbah domestik. Limbah domestic seperti lemak, minyak, dan sampah organic lainnya dapat masuk ke dalam air tanah. Material 
yang masuk ke dalam air tanah ini meningkatkan aktivitas microorganisme pendekomposisi, sehingga mengurangi kadar oksigen dalam air. Keadaan kurang oksigen ini mengakibatkan peningkatan nitrit dan amonium (Bryan dan Lozcalso, 2011; Rawat et al., 2012).

Nitrit dalam air tanah di daerah pemukiman selain berasal dari limbah domestik, diduga nitrit dalam air tanah daerah ini dapat bersumber dari aktivitas pertanian di desa Penfui timur. Aktivitas pertanian di desa ini tidak seintensif aktivitas di kelurahan Tarus. Hal ini berhubungan dengan keterbatasan air di desa tersebut. Penanaman padi dilakukan satu kali dalam setahun, dengan dosis pupuk urea yang lebih rendah dari daerah Tarus yakni $100 \mathrm{~kg} \mathrm{ha}$ ${ }^{1}$ sampai $200 \mathrm{~kg} \mathrm{ha}^{-1}$. Kadar nitrat pada air permukaan di desa Penfui timur telah dianalisis oleh mahasiswa Ilmu Lingkungan Pascasarjana Undana pada bulan januari 2013. Hasil analisis dengan spektrofotometer menunjukkan kadar nitrat pada air permukaan tersebut sebesar $2.70 \mathrm{mg}$ $\mathrm{L}^{-1}$.

Informasi di atas menunjukan adanya nitrit dalam air tanah di daerah pemukiman, walaupun ada sampel air tanah yang tidak terdeteksi kadar nitrit di dalamnya. Karena itu, perlu ada tindakan pencegahan untuk mengurangi dampak negatif dari keberadaan nitrit dalam sumber air minum, mengingat warga yang memanfaatkan sepuluh sumur tersebut tidak memiliki sumber air minum yang lain. Tindakan pencegahan yang dapat dilakukan adalah dengan melakukan pemantauan kadar nitirit dalam air sumur secara periodik.

Hasil pemantauan secara periodic terhadap air tanah dapat dibandingkan dengan baku mutu yang telah ditetapkan. Baku mutu untuk nitrit di dalam air minum telah ditetapkan pemerintah di dalam PP 82 tahun 2001 sebesar $0.06 \mathrm{mg} \mathrm{L}^{-1}$ dan PerMenKes 492 tahun 2010 sebesar $0.9 \mathrm{mg} \mathrm{L}^{-1}$. Berdasarkan nilai tetapan tersebut maka diketahui bahwa kandungan nitrit di dalam air tanah pada daerah pemukiman masih layak dikonsumsi karena berada di bawah baku mutu yang ditetapkan.

\section{Kadmium Persawahan}

Hasil analisis kadar kadmium air tanah dari sumur di daerah persawahan di kelurahan Tarus, menunjukan bahwa Sembilan dari sepuluh sampel yang dianalisis mengandung kadmium di atas batas deteksi alat pendeteksi (AAS). Kandungan kadmium di dalam Sembilan sampel air tanah tersebut adalah $0.53 \times 10^{-2} \mathrm{mg} \mathrm{L}^{-1}, 1.76 \times 10^{-2} \mathrm{mg}$ $\mathrm{L}^{-1}, 1.41 \times 10^{-2} \mathrm{mg} \mathrm{L}^{-1}, 3.87 \times 10^{-2} \mathrm{mg} \mathrm{L}^{-1}, 5.11 \times 10^{-2} \mathrm{mg} \mathrm{L}^{-}$ $1,5.99 \times 10^{-2} \mathrm{mg} \mathrm{L}^{-1}, 6.69 \times 10^{-2} \mathrm{mg} \mathrm{L}^{-1}, 7.04 \times 10^{-2} \mathrm{mg} \mathrm{L}^{-1}$ dan $7.04 \times 10^{-2} \mathrm{mg} \mathrm{L}^{-1}$, seperti yang terlihat pada Tabel 3 berikut.

Kandungan kadmium di dalam air tanah ini dapat diketahui keamanannya untuk dikonsumsi dengan cara membandingkannya dengan baku mutu air dan air minum yang telah ditetapkan di dalam PP 82 tahun 2001 dan PerMenKes 492 tahun 2010. Berdasarkan PP 82 tahun 2001, baku mutu yang ditetapkan untuk kadar kadmium di dalam air minum adalah sebesar $1 \times 10^{-2} \mathrm{mg} \mathrm{L}^{-1}$ sedangkan berdasarkan PerMenKes 492 tahun 2010 sebesar $3 \times 10^{-3}$ $\mathrm{mg} \mathrm{L}^{-1}$.
Tabel 3. Konsentrasi kadmium pada daerah persawahan dan baku mutu

\begin{tabular}{cccc}
\hline \multirow{2}{*}{ Sampel } & Konsentrasi & $\begin{array}{c}\text { Baku mutu } \\
\text { menurut PP 82 } \\
\left(1 \times 10^{-2}\right)\end{array}$ & $\begin{array}{c}\text { Baku mutu menurut } \\
\text { PerMenKes 492 } \\
\left(3 \times 10^{-3}\right)\end{array}$ \\
\cline { 2 - 4 } 1 & \multicolumn{3}{c}{$\mathrm{mg} \mathrm{L}^{-1}$} \\
2 & $0.53 \times 10^{-2}$ & $<\mathrm{BM}$ & $<\mathrm{BM}$ \\
3 & $1.76 \times 10^{-2}$ & $>\mathrm{BM}$ & $>\mathrm{BM}$ \\
4 & $1.41 \times 10^{-2}$ & $>\mathrm{BM}$ & $>\mathrm{BM}$ \\
5 & $3.87 \times 10^{-2}$ & $>\mathrm{BM}$ & $>\mathrm{BM}$ \\
6 & $5.11 \times 10^{-2}$ & $>\mathrm{BM}$ & $>\mathrm{BM}$ \\
7 & $5.99 \times 10^{-2}$ & $>\mathrm{BM}$ & $>\mathrm{BM}$ \\
8 & $6.69 \times 10^{-2}$ & $>\mathrm{BM}$ & $>\mathrm{BM}$ \\
9 & $7.04 \times 10^{-2}$ & $>\mathrm{BM}$ & $>\mathrm{BM}$ \\
10 & $7.04 \times 10^{-2}$ & $>\mathrm{BM}$ & $>\mathrm{BM}$ \\
\hline
\end{tabular}

Keterangan: Kadar kadmium hasil pengukuran AAS dengan $\mathrm{R}^{2}$ absorbsi $=0.999 ;<\mathrm{BM}=$ lebih kecil dari baku mutu; > BM = lebih besar dari baku mutu.

Perbandingan antara kandungan kadmium di dalam air tanah dan baku mutu dari PP 82 tahun 2001 menunjukkan bahwa delapan sampel air tanah melebihi ambang batas yang telah ditetapkan yaitu $>1 \times 10^{-2} \mathrm{mg} \mathrm{L}$ 1. Sedangkan berdasarkan PerMenKes 492 tahun 2010, Sembilan sampel air tanah tersebut telah melebihi ambang batas yang telah ditetapkan yaitu $>3 \times 10^{-3} \mathrm{mg} \mathrm{L}^{-1}$.

\section{Kadmium Pemukiman}

Hasil analisis menunjukan bahwa dari sepuluh sampel yang diambil, Sembilan sampel terdeteksi adanya kandungan. Kandungan kadmiumdari Sembilan sampel air tanah tersebutadalah $0.35 \times 10^{-2} \mathrm{mg} \mathrm{L}^{-1}, 0.35 \times 10^{-2} \mathrm{mg} \mathrm{L}$ $1,2.11 \times 10^{-2} \mathrm{mg} \mathrm{L}^{-1}, 4.05 \times 10^{-2} \mathrm{mg} \mathrm{L}^{-1}, 4.93 \times 10^{-2} \mathrm{mg} \mathrm{L}^{-}$ $1,6.87 \times 10^{-2} \mathrm{mg} \mathrm{L}^{-1}, 8.63 \times 10^{-2} \mathrm{mg} \mathrm{L}^{-1}, 9.33 \times 10^{-2} \mathrm{mg} \mathrm{L}^{-}$ ${ }^{1}$, dan $8.63 \times 10^{-2} \mathrm{mg} \mathrm{L}^{-1}$, hal ini dapat dilihat pada Tabel 4 di bawah ini.

Tabel 4. Konsentrasi kadmium di daerah pemukiman dan baku mutu

\begin{tabular}{cccc}
\hline Sampel & Konsentrasi & $\begin{array}{c}\text { Baku mutu } \\
\text { menurut PP 82 } \\
\left(1 \times 10^{-2}\right)\end{array}$ & $\begin{array}{c}\text { Baku mutu menurut } \\
\text { PerMenKes 492 } \\
\left(3 \times 10^{-3}\right)\end{array}$ \\
\cline { 2 - 4 } $\mathrm{mg} \mathrm{L}^{-1}$ & $>\mathrm{BM}$ \\
\hline 1 & $0.35 \times 10^{-2}$ & $<\mathrm{BM}$ & $<\mathrm{BM}$ \\
3 & $<1 \times 10^{-3}$ & $<\mathrm{BM}$ & $>\mathrm{BM}$ \\
4 & $0.35 \times 10^{-2}$ & $<\mathrm{BM}$ & $>\mathrm{BM}$ \\
5 & $2.11 \times 10^{-2}$ & $>\mathrm{BM}$ & $>\mathrm{BM}$ \\
6 & $4.05 \times 10^{-2}$ & $>\mathrm{BM}$ & $>\mathrm{BM}$ \\
7 & $4.93 \times 10^{-2}$ & $>\mathrm{BM}$ & $>\mathrm{BM}$ \\
8 & $6.87 \times 10^{-2}$ & $>\mathrm{BM}$ & $>\mathrm{BM}$ \\
9 & $8.63 \times 10^{-2}$ & $>\mathrm{BM}$ & $>\mathrm{BM}$ \\
10 & $9.33 \times 10^{-2}$ & $>\mathrm{BM}$ & $>\mathrm{BM}$ \\
\hline Keteran & $8.63 \times 10^{-2}$ & $>\mathrm{BM}$ & $\mathrm{B}$ \\
\hline
\end{tabular}

Keterangan: Kadar kadmium hasil pengukuran AAS dengan $\mathrm{R}^{2}$ absorbsi $=0.999$; $<\mathrm{BM}=$ lebih kecil dari baku mutu; > BM = lebih besar dari baku mutu.

Berdasarkan data di atas diketahui bahwa sebagian besar air tanah telah terkontaminasi oleh kadmium. Karena itu diperlukan adanya pemantauan secara periodic terhadap air tanah dari sumur-sumur yang dimanfaatkan sebagai air minum. Pemantauan yang dilakukan dapat menghasilkan informasi tentang kadar cadmium dalam air tanah. Kadar cadmium tersebut, selanjutnya dapat dibandingkan dengan baku mutu air yang 
ada di dalam PP 82 tahun 2001 dan PerMenKes 492 tahun 2010 .

Nilai baku mutu untuk kadar kadmium di dalam air tanah berdasarkan PP 82 tahun 2001 adalah sebesar $1 \mathrm{x}$ $10^{-2} \mathrm{mg} \mathrm{L}^{-1}$ dan berdasarkan PerMenKes 492 tahun 2010 sebesar3 x $10^{-3} \mathrm{mg} \mathrm{L}^{-1}$. Hasil perbandingan 9 sampel air tanah dengan baku mutu menunjukkan bahwa tujuh sampel air tanah telah melebihi ambang batas yang ditetapkan PP 82 tahun 2001. Sedangkan berdasarkan PerMenKes 492 tahun 2010, Sembilan sampel air tanah tersebut mempunyai kandungan kadmium yang melebihi ambang batas.

Informasi yang didapat dari perbandingan dengan baku mutu yang ada di dalam PP 82 tahun 2001 dan PerMenKes 492 tahun 2010, dapat disesuaikan juga dengan metode lainnya yang dapat memprediksi risiko. Salah satu metode yang dapat digunakan adalah analisis risiko kesehatan.

\section{Prediksi Risiko Nitrit}

Prediksi risiko nitrit dari air pada sumur-sumur di daerah persawahan dan pemukiman telah dilakukan dan dapat dilihat pada Tabel 5 di bawah ini.

Tabel 5. Prediksi risiko nitrit dalam air tanah di Tarus

\begin{tabular}{|c|c|c|c|c|}
\hline \multirow[t]{2}{*}{ Sampel } & Konsentrasi & $\begin{array}{c}\text { Asupan Harian } \\
\left(\mathrm{I}_{\mathrm{nk}}\right)\end{array}$ & \multirow{2}{*}{$\begin{array}{c}\text { Tingkat } \\
\text { Risiko } \\
\text { (RQ) }\end{array}$} & \multirow[t]{2}{*}{ Ket } \\
\hline & $\mathrm{mg} \mathrm{L}^{-1}$ & $\mathrm{mg} \mathrm{kg}^{-1}$ hari $^{-1}$ & & \\
\hline 1 & $0.24 \times 10^{-2}$ & $8.41 \times 10^{-5}$ & $8.41 \times 10^{-4}$ & TB \\
\hline 2 & $0.24 \times 10^{-4}$ & $8.37 \times 10^{-7}$ & $8.37 \times 10^{-6}$ & $\mathrm{~TB}$ \\
\hline 3 & $1.24 \times 10^{-2}$ & $4.31 \times 10^{-4}$ & $4.31 \times 10^{-3}$ & TB \\
\hline 4 & $0.75 \times 10^{-3}$ & $2.62 \times 10^{-5}$ & $2.62 \times 10^{-4}$ & TB \\
\hline 5 & $1.26 \times 10^{-2}$ & $4.39 \times 10^{-4}$ & $4.39 \times 10^{-3}$ & $\mathrm{~TB}$ \\
\hline 6 & $1.72 \times 10^{-3}$ & $5.99 \times 10^{5}$ & $5.99 \times 10^{-4}$ & TB \\
\hline 7 & $1.96 \times 10^{-3}$ & $6.83 \times 10^{-5}$ & $6.83 \times 10^{-4}$ & $\mathrm{~TB}$ \\
\hline 8 & $1.48 \times 10^{-3}$ & $5.15 \times 10^{-5}$ & $5.15 \times 10^{-4}$ & $\mathrm{~TB}$ \\
\hline
\end{tabular}

Keterangan: Prediksi risiko dengan menggunakan nilai default; $\mathrm{TB}=$ nilai tingkat risiko $<1=$ tidak berisiko.

Nilai tingkat risiko (RQ) untuk nitrit menunjukan bahwa sumur-sumur di kelurahan Tarus masih berada dalam taraf aman untuk dikonsumsi. Hal ini terlihat dari nilai RQ yang masih lebih kecil dari 1 . Namun perlu dijaga agar nilai RQ ini tidak terus bertambah hingga melampui nilai ambang batas yang ditetapkan.

\section{Prediksi Risiko Kadmium Persawahan}

Predisksi risiko Terhadap konsumsi air dari sumur-sumur yang mengandung kadmium di daerah persawahan dapat diamati pada Tabel 6 di bawah ini.

Berdasarkan analisis risiko yang dilakukan diketahui bahwa dari sepuluh sampel air tanah yang diteliti, dua sampel belum berisiko, dan satu sampel dengan nilai RQ 0.984 perlu mendapat perhatian serius, serta tujuh sampel telah berada dalam kondisi berisiko.

Risiko yang ditimbulkan kadmium dalam air tanah ini ditunjukkan oleh nilai RQ yang lebih besar dari 1 (RQ > 1). Kadmium yang berisiko ini, sangat berbahaya ketika telah masuk ke dalam tubuh. Hal ini dikarenakan kadmium merupakan unsur yang beracun dan tidak mudah hilang melalui paru-paru ketika bernapas, dan sangat sedikit yang keluar dari tubuh ketika makanan atau air terbuang dari tubuh melaui feses (ATSDR, 1999).
Akibatnya, kadmium akan terbawa ke dalam hati dan ginjal dan tertimbun selama bertahun-tahun. Hal inilah yang dapat mengakibatkan timbulnya penyakit hingga kematian karena toksisitas kronis dari kadmium.

Tabel 6. Prediksi risiko kadmiun dalam air tanah daerah persawahan

\begin{tabular}{|c|c|c|c|c|}
\hline \multirow[b]{2}{*}{ Sampel } & Konsentrasi & Asupan Harian $\left(\mathrm{I}_{\mathrm{nk}}\right)$ & \multirow{2}{*}{$\begin{array}{l}\text { Tingkat } \\
\text { Risiko } \\
\text { (RQ) }\end{array}$} & \multirow[b]{2}{*}{ Ket } \\
\hline & $\mathrm{mg} \mathrm{L}^{-1}$ & $\mathrm{mg} \mathrm{kg}^{-1}$ hari $^{-1}$ & & \\
\hline 1 & $<1 \times 10^{-3}$ & & & TB \\
\hline 2 & $0.53 \times 10^{-2}$ & $1.85 \times 10^{-4}$ & 0.37 & $\mathrm{~TB}$ \\
\hline 3 & $1.76 \times 10^{-2}$ & $6.14 \times 10^{-4}$ & 1.228 & B \\
\hline 4 & $1.41 \times 10^{-2}$ & $4.92 \times 10^{-4}$ & 0.984 & $\mathrm{~TB}$ \\
\hline 5 & $3.87 \times 10^{-2}$ & $13.49 \times 10^{-4}$ & 2.698 & B \\
\hline 6 & $5.11 \times 10^{-2}$ & $17.82 \times 10^{-4}$ & 3.564 & B \\
\hline 7 & $5.99 \times 10^{-2}$ & $20.89 \times 10^{-4}$ & 4.178 & B \\
\hline 8 & $6.69 \times 10^{-2}$ & $23.33 \times 10^{-4}$ & 4.666 & B \\
\hline 9 & $7.04 \times 10^{-2}$ & $24.55 \times 10^{-4}$ & 4.91 & B \\
\hline 10 & $7.04 \times 10^{-2}$ & $24.55 \times 10^{-4}$ & 4.91 & $\mathrm{~B}$ \\
\hline ato & $\begin{array}{l}\text { prediksi ris } \\
\mathrm{TB}=\text { nilai } \\
\text { nilai tingka }\end{array}$ & $\begin{array}{l}\text { engan menggur } \\
\text { at risiko }<1= \\
\text { xo }>1=\text { berisiko }\end{array}$ & nilai & $\begin{array}{l}\text { ult; } \\
3=\end{array}$ \\
\hline
\end{tabular}

\section{Prediksi Risiko Kadmium Pemukiman}

Predisksi risiko Terhadap konsumsi air dari sumur-sumur yang menngandung cadmium di daerah pemukiman dapat diamati pada Tabel 7 di bawah ini.

Tabel 7. Prediksi risiko kadmium dalam air tanah daerah pemukiman

\begin{tabular}{|c|c|c|c|c|}
\hline \multirow[b]{2}{*}{ Sampel } & Konsentrasi & Asupan Harian $\left(\mathrm{I}_{\mathrm{nk}}\right)$ & \multirow{2}{*}{$\begin{array}{c}\text { Tingkat } \\
\text { Risiko } \\
\text { (RQ) }\end{array}$} & \multirow[b]{2}{*}{ Ket } \\
\hline & $\mathrm{mg} \mathrm{L}^{-1}$ & $\mathrm{mg} \mathrm{kg}^{-1}$ hari $^{-1}$ & & \\
\hline 1 & $0.35 \times 10^{-2}$ & $1.22 \times 10^{-4}$ & 0.244 & TB \\
\hline 2 & $<1 \times 10^{-3}$ & & & TB \\
\hline 3 & $0.35 \times 10^{-2}$ & $1.22 \times 10^{-4}$ & 0.244 & $\mathrm{~TB}$ \\
\hline 4 & $2.11 \times 10^{-2}$ & $7.36 \times 10^{-4}$ & 1.472 & B \\
\hline 5 & $4.05 \times 10^{-2}$ & $14.12 \times 10^{-4}$ & 2.824 & B \\
\hline 6 & $4.93 \times 10^{-2}$ & $17.19 \times 10^{-4}$ & 3.438 & B \\
\hline 7 & $6.87 \times 10^{-2}$ & $23.96 \times 10^{-4}$ & 4.792 & B \\
\hline 8 & $8.63 \times 10^{-2}$ & $30.09 \times 10^{-4}$ & 6.018 & B \\
\hline 9 & $9.33 \times 10^{-2}$ & $32.53 \times 10^{-4}$ & 6.506 & B \\
\hline 10 & $8.63 \times 10^{-2}$ & $30.09 \times 10^{-4}$ & 6.018 & B \\
\hline
\end{tabular}

Keterangan: prediksi risiko dengan menggunakan nilai default; $\mathrm{TB}=$ nilai tingkat risiko $<1=$ tidak berisiko; $\mathrm{B}=$ nilai tingkat risiko $>1=$ berisiko.

Analisis risiko yang dilakukan terhadap kesepuluh sampel air di daerah pemukiman menunjukan bahwa, tiga sampel air tanah tidak berisiko, sedangkan tujuh sampel air tanah telah berisiko untuk dikonsumsi sebagai air minum.

Nilai RQ yang kurang dari satu (RQ $<1)$ menunjukkan bahwa air tanah tersebut masih aman untuk dikonsumsi, sedangkan jika telah melebihi satu (RQ > 1) maka air tanah tersebut telah berisiko untuk dikonsumsi. Tingkat risiko ini dapat dialami warga dengan berat badan $55 \mathrm{~kg}$, dan mengkonsumsi air tanah tersebut sebanyak dua liter perhari selama tigapuluh tahun. Informasi tingkat risiko dengan durasi waktu yang lebih pendek diperlukan untuk meminimalkan dampak negatif dari paparan kadmium bagi kesehatan manusia. 


\section{SIMPULAN}

Berdasarkan hasil penelitian, dapat disimpulkan bahwa terdapat nitrit dan cadmium terdeteksi di dalam sampel air tanah, namun kadar nitrit di dalam air tanah masih berada di bawah standar baku mutu yang ditetapkan PP 82 tahun 2001 dan PerMenKes 492 tahun 2010, sedangkan kadar kadmium di dalam 15 sampel air tanah telah melebihi standar baku mutu.

Analisis risiko kesehatan menunjukkan bahwa, nitrit yang ada pada air dari sumur-sumur di daerah persawahan dan pemukiman masih aman untuk dikonsumsi. Sedangkan untuk unsur kadmium, air dari empat belas sumur di daerah persawahan dan pemukiman berisiko untuk dikonsumsi.

\section{DAFTAR PUSTAKA}

Agency for Toxic Subtance and Desease Registry. 2005. Public Health Assessment Guadance Manual. US Departemen of Health and Human Services. USA

Agency for Toxic Subtance and Desease Registry. 1999. Toxicological Profile for Cadmium. US Departemen of Health and Human Services. USA

Agency for Toxic Subtance and Desease Registry. 2012. Toxicological Profile for Cadmium. US Departemen of Health and Human Services. USA

Akiwumi, O.O., O.A. Elleta and O. Odebunmi. 2012. Analysis of nitrates and nitrites in groundwater of ilorin environs. Journal of Environmental Scince and Engineering, A 1:656-662.

Alloway, B.J. and D.C. Ayres. 1993. Chemical principles of environmental pollution. Blackie academic \& Professional. London. UK.

Arikunto, S. 2002. Prosedur penelitian (Suatu Pendekatan Praktek). Penerbit Rineka Cipta. Jakarta.

Aswadi, M. 2006. Pemodelan fluktuasi nitrogen (nitrit) pada aliran sungai Palu. Smartek Sipil Mesin Arsitektur Elektro. Fakultas Teknik-Universitas Tadulako. Palu.

Badan Standar Nasional. 2008. Standar Nasional Indonesia (SNI) 6989.58:2008. Air dan air limbah - Bagian 58: Metoda pengambilan contoh air tanah. Banten.

Badan Standar Nasional. 2004. Standar Nasional Indonesia (SNI) 06-6989.9-2004. 2004. Air dan air limbah Bagian 9: Cara uji nitrit $\left(\mathrm{N}-\mathrm{NO}_{2}\right)$ secara spektrofotometri. Banten.

Badan Standar Nasional. 2009. Standar Nasional Indonesia (SNI) 6989.16:2009. 2009. Air dan air limbah Bagian 16: Cara uji kadmium (Cd) secara Spektrofotometri Serapan Atom (SSA)-Nyala. Banten.
Bryan, N.S. and J. Lozcalso. 2011. Nitrite and nitrate in human health and disease. Humana Press. United State of America.

Dimopoulus, M., M. Chalkiadaki, M. Dassenakis and M. Scoullos. 2003. Quality of ground water in western thesally the problem of nitrate pollution. Global Nest International Journal, 5(3): 185-191.

Effendi, H. 2003. Telaah kualitas air bagi pengelolaan sumberdaya dan lingkungan perairan. Penerbit Kansius. Yogyakarta.

Genafati, S.P., Istiqomah dan Purwanto. 2005. Pengelolaan air minum sumur gali untuk rumah tangga secara aerasi, filtrasi dan disinfeksi. Jurnal Teknologi Lingkungan, P3TL-BPPT, 6(1): 262-267.

Peraturan Pemerintah Nomor 82. 2001. Pengelolaan kualitas air dan pengendalian pencemaran air.

Peraturan Menteri Kesehatan Republik Indonesia. Nomor 492. 2010. Persyaratan kualitas air minum.

Raja, G. and P. Vankatesan. 2010. Assesment of groundwater polution and its impact in and around Punnam area of Karur District, Tamilnadu, India. EJournal of Chemistry, 7(2): 473-478.

Rawat, S.K., R.K. Singh and R.P. Singh. 2012. Remediation of nitrite contamination in ground and surface waters using aquatic macrophytes. Journal Environmental Biol., 33: 51-56.

Slamet, J.S. 2002. Kesehatan lingkungan. Gadjah Mada University Press. Yogyakarta.

Sugiyono. 2007. Statistika untuk penelitian. Penerbit Alfabeta. Bandung.

Suwari, 2011. Inventarisasi sumberdaya air pulau Timor propinsi Nusa Tenggara Timur. Pusat Penelitian Lingkungan Hidup-Universitas Nusa Cendana. Kupang.

Tiwari, R.N. 2011. Assesment of groundwater quality and pollution potential of Jawa Block Rewa District, Madhya Pradesh, India. Proceeding of the International Academy of Ecology and Environmental Sciences, 1(3-4):202-212

UNESCO'S International Hydrological Programe. 2011. The Impact of Global Change on Water Resources.

Utama, H. 2007. Keracunan nitrat-nitrit. Didownload November 2012.

Villa, I.G. 2010. Agriculture contamination of subterranean water with nitrates and nitrites: An Evironmental and Public Health Problem. Journal of Agricultural Science, 2(2): 17-30. 